\title{
THE INFLUENCE OF BUDGET PARTICIPATION AND ORGANIZATIONAL COMMITMENT TO MANAGERIAL PERFORMANCE (Case Study at PT. Adhi Karya Persero Tbk)
}

\author{
Maya Widyana Dewi, ${ }^{1)}$ Suhesti Ningsih ${ }^{2)}$ \\ ITB AAS Indonesia \\ E-mail: ${ }^{1)}$ widyamine77@gmail.com, ${ }^{21}$ hesti.hegi@gmail.com
}

\begin{abstract}
This study aims to examine the effect of budgeting and organizational commitment on managerial performance. The data collection of this study using questionnaires, as many as 70 questionnaires filled out completely and can be processed. Data were analyzed using descriptive statistical tests, validity and reliability tests, while hypothesis testing used multiple linear regression tests, $t$ tests, $F$ tests and the coefficient of determination (R2). The results showed that budgetary participation variables had a significant effect on managerial performance. The higher employee participation the higher the level of managerial performance. The variable organizational commitment has a significant effect on managerial performance. Thus the higher one's commitment to the organization, the higher the level of managerial performance. From the $F$ test the variable budget participation and organizational commitment together (simultaneously) significantly influence managerial performance with the percentage of influence of $69.2 \%$ and the remaining $30.8 \%$ influenced by other variables outside this study.
\end{abstract}

Keywords : Budget Participation, Organizational Commitment, Managerial Performance

\section{Introduction}

In this era, only companies that are able to do efficiency, improve quality, and managerial performance of a company that is able to maintain the survival of the company in the midst of increasingly fierce business competition. Managerial performance is the result of an effective managerial activity process starting from the process of planning, implementation, administration, accountability reports, guidance and supervision

The success of a company's managerial performance is supported by factors within the company, including budgetary participation and organizational commitment. Budgetary participation is a form of employee participation in budgeting, where the budget acts as a measure of company performance. The budget is a plan of actions in the future to achieve organizational goals. In business organizations, the intended purpose is to seek profit (profit oriented), while non-business organizations are not (nonprofit oriented). Because the objectives are different, the work plans that are prepared are also different. As such, approaches to budgeting in the two types of organizations are also different.

One of the most popular approaches especially related to increasing employee motivation and performance is participatory budgeting. In the business literature, employee involvement is very important in determining targets (eg production and sales) and the amount of compensation (incentives) associated with the performance achieved. In this approach, employees are involved 
International Journal of Economics, Business and Accounting Research (IJEBAR)

Peer Reviewed - International Journal

Vol-4, Issue-2, 2020 (IJEBAR)

E-ISSN: 2614-1280 P-ISSN 2622-4771

http://jurnal.stie-aas.ac.id/index.php/IJEBAR

in determining their performance targets and the amount of incentives (such as bonuses and other compensation) if the target is achieved.

Organizational commitment according to Cut Zurnali (2010) is a psychological condition that characterizes employee relations with the organization or its implications that affect whether employees will remain in the organization or not, which are identified in three components, namely: affective commitment, continuous commitment and normative commitment. Commitment strong organizations will encourage individuals strive to achieve organizational goals and through organizational commitment no will directly improve managerial performance. High organizational commitment increase high performance too.

the results of previous research (Wahyuningsih, 2005) which states that budgetary participation significantly influences managerial performance. Research conducted by Arisandi (2007) also states that increasing participation in budgeting will improve managerial performance. Previous research by Elinda (2015) states that the participation budgeting, organizational commitment and environmental uncertainty have a significant effect on managerial performance and Prasetyo's research (2018) states that budgetary participation partially does not significantly influence managerial performance, while organizational commitment partially influences managerial performance. Simultaneously both of them significantly influence managerial performance. Research by by Anggraeni (2010) which states that organizational commitment has a significant influence on managerial performance.

From the above study, the research framework is as follows:

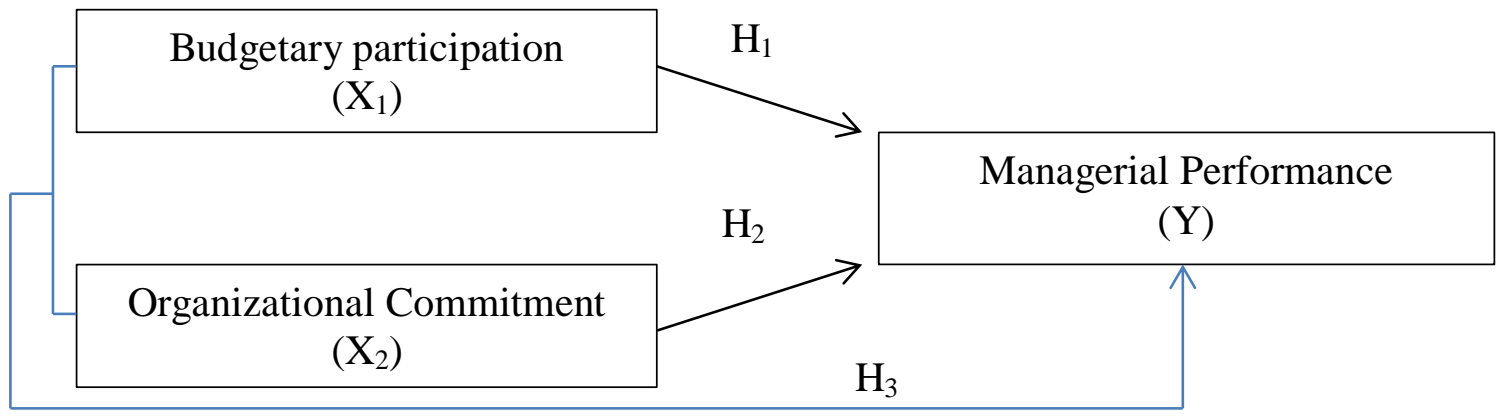

Gambar 1 Framework Research

Based on the framework in this research, the following hypotheses are drawn:

$\mathrm{H}_{1} \quad$ : Budget participation significantly influences managerial performance

$\mathrm{H}_{2}$ : Organizational commitment significantly influences managerial performance

$\mathrm{H}_{3}$ : Budgetary participation and organizational commitment simultaneously influence managerial performance

\section{Research Method}

The population in this study were all employees of PT Adhi Karya Persero Tbk. Whereas the research sample was taken using a purposive sampling technique that is data source sampling techniques (Sugiyono, 2016). The consideration used to determine the sample is employees who work in the company's management department, where the total sample is 70 employees. 
Vol-4, Issue-2, 2020 (IJEBAR)

E-ISSN: 2614-1280 P-ISSN 2622-4771

http://jurnal.stie-aas.ac.id/index.php/IJEBAR

Research data using primary data and secondary data. Primary data obtained from questionnaires distributed to employees with four alternative answers, namely strongly agree, agree, disagree, strongly disagree. While secondary data were obtained from book references and references from PT Adhi Karya Persero Tbk.

The variables of this study are divided into two, namely the dependent variable that is influenced by other variables represented by managerial performance and the independent variable, namely the variables that affect other variables represented by budgetary participation and organizational commitment.

Data analysis techniques used are descriptive statistical analysis techniques, validity and reliability testing. while testing the hypothesis using multiple linear regression test, $t$ test, $F$ test and the coefficient of determination $\left(\mathrm{R}^{2}\right)$ test

\section{Results and Discussion}

\subsection{Results}

Table 1 Summary of Descriptive Statistics of Research Variables

\begin{tabular}{|c|c|c|c|c|c|}
\hline & $\mathrm{N}$ & Minimum & Maximum & Mean & $\begin{array}{c}\text { Std. } \\
\text { Deviation }\end{array}$ \\
\hline $\begin{array}{c}\text { BUDGET PARTICIPATION } \\
\text { (X1) }\end{array}$ & 70 & 15 & 20 & 17,61 & 1,467 \\
$\begin{array}{c}\text { ORGANIZATIONAL } \\
\text { COMMITMENT (X2) } \\
\text { MANAGERIAL } \\
\text { PERFORMANCE (Y) } \\
\text { Valid N (listwise) }\end{array}$ & 70 & 15 & 20 & $17, .51$ & 1,511 \\
\hline
\end{tabular}

The results of the descriptive statistical analysis in the table above are:

1. Budget participation has a minimum value of 15 and a maximum value of 20 . The average value of budget participation is 17,61 and the standard deviation value is 1.467.

2. Organizational Commitment has a minimum value of 15 and a maximum value of 20 . The average value of Organizational Commitment is 17,51 and the standard deviation value is 1,511 .

3. Managerial Performance has a minimum value of 15 and a maximum value of 20 . The average value of Managerial Commitment is 17,53 and the standard deviation value is 1,520 . 
International Journal of Economics, Business and Accounting Research (IJEBAR)

Peer Reviewed - International Journal

Vol-4, Issue-2, 2020 (IJEBAR)

E-ISSN: 2614-1280 P-ISSN 2622-4771

http://jurnal.stie-aas.ac.id/index.php/IJEBAR

Table 2 Test Data Validity

\begin{tabular}{|c|c|c|c|c|}
\hline No & Item Questions & $\begin{array}{c}\text { Pearson Correlation }(\mathrm{r} \\
\text { Calculate }\end{array}$ & $\mathrm{r}$ Table & conclusion \\
\hline 1 & $\mathrm{X} 1.1$ & 0,667 & 0,239 & Valid \\
\hline 2 & $\mathrm{X} 1.2$ & 0,623 & 0,239 & Valid \\
\hline 3 & $\mathrm{X} 1.3$ & 0,584 & 0,239 & Valid \\
\hline 4 & $\mathrm{X} 1.4$ & 0,769 & 0,239 & Valid \\
\hline 5 & $\mathrm{X} 1.5$ & 0,701 & 0,239 & Valid \\
\hline 6 & $\mathrm{X} 2.1$ & 0,734 & 0,239 & Valid \\
\hline 7 & $\mathrm{X} 2.2$ & 0,661 & 0,239 & Valid \\
\hline 8 & $\mathrm{X} 2.3$ & 0,580 & 0,239 & Valid \\
\hline 9 & $\mathrm{X} 2.4$ & 0,730 & 0,239 & Valid \\
\hline 10 & $\mathrm{X} 2.5$ & 0,678 & 0,239 & Valid \\
\hline 11 & $\mathrm{Y} 1$ & 0,700 & 0,239 & Valid \\
\hline 12 & $\mathrm{Y} 2$ & 0,569 & 0,239 & Valid \\
\hline 13 & $\mathrm{Y} 3$ & 0,653 & 0,239 & Valid \\
\hline 14 & $\mathrm{Y} 4$ & 0,621 & 0,239 & Valid \\
\hline 15 & $\mathrm{Y} 5$ & 0,757 & & \\
\hline
\end{tabular}

The validity test results in table 2 show the $\mathrm{r}$ count of all question items is greater than $\mathrm{r}$ table (0.239) meaning that all the item questions in the research questionnaire are said to be valid and can be trusted to collect the data needed and can be further processed.

Table 3 Data Reliability Test

\begin{tabular}{|l|l|c|c|}
\hline No & \multicolumn{1}{|c|}{ Variable } & Cronbach's Alpha & Information \\
\hline 1 & Budget Participation & 0,688 & Reliabel \\
\hline 2 & Organizational Commitment & 0,703 & Reliabel \\
\hline 3 & Managerial Performance & 0,680 & Reliabel \\
\hline
\end{tabular}

Based on Table 3 above states that all research variable instruments have a Cronbach Alpha value of more than 0.6. Thus it can be concluded that all research variables are reliable.

Table 4 Results of Multiple Regression Analysis

Coefficients $^{\mathrm{a}}$

\begin{tabular}{|c|c|c|c|c|c|c|c|}
\hline \multirow[b]{2}{*}{ Model } & \multicolumn{2}{|c|}{$\begin{array}{c}\text { Unstandardized } \\
\text { Coefficients }\end{array}$} & \multirow{2}{*}{$\begin{array}{c}\text { Standardized } \\
\text { Coefficients } \\
\text { Beta }\end{array}$} & \multirow[b]{2}{*}{$\mathrm{T}$} & \multirow[b]{2}{*}{ Sig. } & \multicolumn{2}{|c|}{ Collinearity Statistics } \\
\hline & B & $\begin{array}{l}\text { Std. } \\
\text { Error }\end{array}$ & & & & Tolerance & VIF \\
\hline $1 \quad$ (Constant) & -3.173 & 1.655 & & -1.918 & .059 & & \\
\hline $\begin{array}{l}\text { BUDGET } \\
\text { PARTICIPATI } \\
\text { ON(X1) }\end{array}$ & .632 & .069 & .610 & 9.131 & .000 & .997 & 1.003 \\
\hline
\end{tabular}

International Journal of Economics, Bussiness and Accounting Research (IJEBAR) Page 417 
International Journal of Economics, Business and Accounting Research (IJEBAR)

Peer Reviewed - International Journal

Vol-4, Issue-2, 2020 (IJEBAR)

E-ISSN: 2614-1280 P-ISSN 2622-4771

http://jurnal.stie-aas.ac.id/index.php/IJEBAR

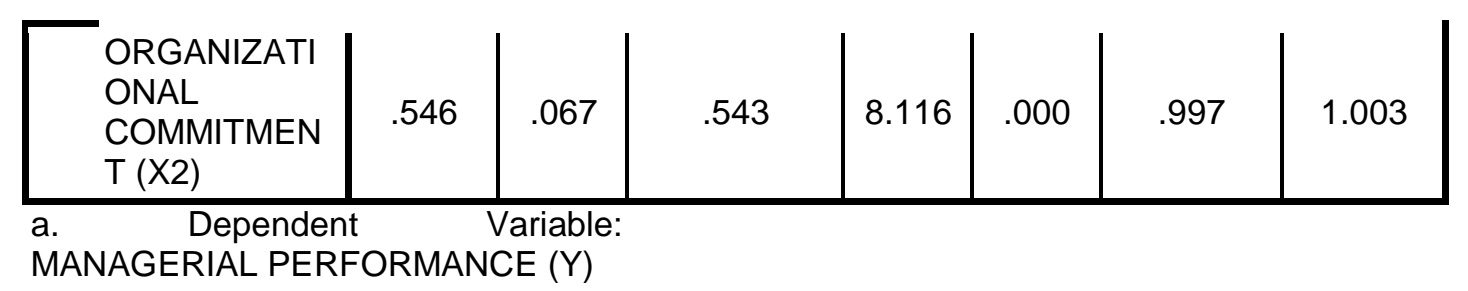

Based on the results of the multiple linear regression test in table 4, the regression equation is as follows:

Manajerial Performance $(Y)=-3,173+0,632$ Budget Participation $\left(X_{1}\right)+0,546$ Organizational Commitment $\left(\mathbf{X}_{2}\right)$

From the regression equation above, it can be interpreted as follows:

1. Constant (absolute value $\mathrm{Y}$ ) of $-3,173$ states if the independent variable is considered constant, then managerial performance is $-3,173$

2. The regression coefficient of Budget Participation of 0.632 states that every time there is an increase in Budget Participation of $1 \%$ it will increase the Managerial Performance of 0.632 or $63.2 \%$

3. Regression coefficient of Organizational Commitment of 0.546 states that every time there is an increase in Organizational Commitment by $1 \%$ it will increase Managerial Performance by 0.546 or $54.6 \%$

Table 5 Test Results of Partial Regression Coefficients

Coefficients $^{\mathrm{a}}$

\begin{tabular}{|c|c|c|c|c|c|c|}
\hline & & \multicolumn{2}{|c|}{$\begin{array}{l}\text { Unstandardized } \\
\text { Coefficients }\end{array}$} & \multirow{2}{*}{$\begin{array}{c}\begin{array}{c}\text { Standardized } \\
\text { Coefficients }\end{array} \\
\text { Beta }\end{array}$} & \multirow[b]{2}{*}{$\mathrm{t}$} & \multirow[b]{2}{*}{ Sig. } \\
\hline \multicolumn{2}{|c|}{ Model } & $B$ & Std. Error & & & \\
\hline \multirow[t]{3}{*}{1} & (Constant) & -3.173 & 1.655 & & -1.918 & .059 \\
\hline & $\begin{array}{l}\text { BUDGET } \\
\text { PARTICIPATION } \\
\text { (X1) }\end{array}$ & .632 & .069 & .610 & 9.131 & .000 \\
\hline & $\begin{array}{l}\text { ORGANIZATIONAL } \\
\text { COMMITMENT (X2) }\end{array}$ & .546 & .067 & .543 & 8.116 & .000 \\
\hline
\end{tabular}

Based on the results of the $t$ test, the results can be interpreted as follows:

1. $t$ count according to budget participation variable (X1) of 9,131 is greater than table $(1,668)$ or significant $t$ for budget participation participation variable (X1) is 0,000 less than $\propto(0.05)$. This means that budgetary participation (X1) significantly influences managerial performance (Y). Thus Ho is rejected and Ha is accepted.

2. $t$ count for variable organizational commitment (X2) of 8.116 is greater than $t$ table (1.668) or significant $t$ for variable organizational commitment (X2) of 0.000 is smaller 
International Journal of Economics, Business and Accounting Research (IJEBAR)

Peer Reviewed - International Journal

Vol-4, Issue-2, 2020 (IJEBAR)

E-ISSN: 2614-1280 P-ISSN 2622-4771

http://jurnal.stie-aas.ac.id/index.php/IJEBAR

than $\propto(0.05)$, this means that organizational commitment (X2) influences significant on managerial performance (Y) thus Ho is rejected and Ha is accepted.

Table 6 Simultaneous Regression Coefficient Tests

ANOVA $^{\text {b }}$

\begin{tabular}{|c|c|c|c|c|c|c|}
\hline \multicolumn{2}{|r|}{ Model } & Sum of Squares & Df & Mean Square & $\mathrm{F}$ & Sig. \\
\hline 1 & Regression & 111.816 & 2 & 55.908 & 78.649 & $.000^{\mathrm{a}}$ \\
\hline & Residual & 47.627 & 67 & .711 & & \\
\hline & Total & 159.443 & 69 & & & \\
\hline
\end{tabular}

a. Predictors: (Constant), ORGANIZATIONAL COMMITMENT (X2), BUDGET

PARTICIPATION $(X 1)$

b. Dependent Variable: MANAGERIAL PERFORMANCE (Y)

Based on the simultaneous regression analysis test shown in Table 6 that F count is 78.664 and $\mathrm{F}$ table is 3.13 so F count is greater than F table then Ho is rejected and Ha is accepted, or the calculated $F$ value of 78.664 with a significant level of 0.000 . The resulting significant value is smaller than $\propto=0.05$. This means that the budgeting participation variable (X1) and organizational commitment variable (X2) simultaneously have a significant effect on the managerial performance variable (Y).

Table 7 Results of the Determination Coefficient Analysis Model Summary ${ }^{\mathrm{b}}$

\begin{tabular}{|c|c|c|c|c|c|}
\hline Model & $\mathrm{R}$ & $\mathrm{R}$ Square & $\begin{array}{c}\text { Adjusted R } \\
\text { Square }\end{array}$ & $\begin{array}{c}\text { Std. Error of the } \\
\text { Estimate }\end{array}$ & Durbin-Watson \\
\hline 1 & $.837^{\mathrm{a}}$ & .701 & .692 & .843 & 2.220 \\
\hline
\end{tabular}

a. Predictors: (Constant), ORGANIZATIONAL COMMITMENT (X2), BUDGET PARTICIPATION (X1)

b. Dependent Variable: MANAGERIAL PERFORMANCE $(\mathrm{Y})$

Based on the calculation results shown in Table 7 above, the Adjusted R Square value is $0.692(69.2 \%)$, meaning that $69.2 \%$ of the managerial performance variable (Y) can be explained by the budget participation variable (X1) and organizational commitment (X2). The rest, which is $30.8 \%$ is explained by other factors outside this study.

\subsection{Discussion}

Testing for the first hypothesis (H1) in this study shows that partially budgeting participation has a significant effect on managerial performance, where tcount is greater than table that is 9,131> 1,668. From the results of the analysis it can be concluded that the budgeting participation variable (X1) has a significant effect on managerial performance variables (Y). This means that managers, section heads and subordinates involved in budget participation in PT. Adhi Karya (Persero) Tbk has a high level of participation. The results of this study support 
research conducted by Wahyuningsih (2005) which states that budgetary participation significantly influences managerial performance. In addition, research conducted by Arisandi (2007) also states that increasing participation in budgeting will improve managerial performance.

Testing for the second hypothesis (H2) in this study shows that partially organizational commitment to managerial performance is proven by tcount greater than ttable, that is equal to 8.116> 1.668. From the results of this analysis it can be concluded that organizational commitment variable (X2) significantly influences managerial performance (Y), this means that employees at PT. Adhi Karya (Persero) Tbk has a high commitment to its organization.

This is in line with the theory previously stated, which states that an organizational commitment is an attitude that reflects an employee's loyalty to the organization and the ongoing process whereby members of the organization express their concern for the organization and success and continued progress towards the goals, values and organizational goals. This research is in line with the theories that have been put forward, as well as what has been done by Anggraeni (2010) which states that organizational commitment has a significant influence on managerial performance and Prasetyo's research (2018) states that Simultaneously both of Budget Participation and Organizational Commitment significantly influence managerial performance.

Testing for the third hypothesis (H3) in this study shows that together (simultaneous) budgeting participation (X1) and organizational commitment (X2) to managerial performance $(\mathrm{Y})$, where Fcount is greater than $\mathrm{F}$ table that is 78,649>3,13. From the results of the analysis it can be concluded that the budgeting participation variable (X1), and organizational commitment (X2) influence jointly (simultaneously) on managerial performance variables (Y). This means that organizational participation and commitment is high so their performance is also high. This research is in line with Kennis's theory, 1979 (in Triyokananta, 2006: 13) states that participation in budgeting as an information exchange mechanism allows employees to gain a clearer understanding of their work. In addition, participation also helps to correct mistakes that can ultimately improve employee performance. Budget participation is also a tool that can be used for control, coordination, work evaluation, and motivation.

Simultaneous testing leads to the percentage of the influence of budgetary participation and organizational commitment of $69.2 \%$ and the remaining $30.8 \%$ is influenced by other factors outside this study

\section{Conclusion}

The conclusion of this research is :

1) Each variable of Budget Participation and Organizational Commitment significantly influences managerial performance. The higher the level of budget participation and organizational commitment, the higher the company's managerial performance. A person who is committed to the organization will show positive attitudes and behaviors towards the organization, as well as trying to increase achievement and have certain confidence to help realize the company's goals.

2) Variable Budget Participation and Organizational Commitment simultaneously influence managerial performance. 
International Journal of Economics, Business and Accounting Research (IJEBAR)

Peer Reviewed - International Journal

Vol-4, Issue-2, 2020 (IJEBAR)

E-ISSN: 2614-1280 P-ISSN 2622-4771

http://jurnal.stie-aas.ac.id/index.php/IJEBAR

3) The strength of the influence of the independent variable budgetary participation and organizational commitment to managerial performance is $69.2 \%$. The rest, which is $30.8 \%$ is explained by other factors not explained in this study.

The recommendations of this study are :

1) For further research

a. Future studies are expected to examine other factors that can improve managerial performance in addition to budgetary participation, and organizational commitment. By using a combination of variables that include other internal factors and also external factors that can affect managerial performance.

b. Studying more deeply on a broader scope or at other companies, so that the results of further research are expected to make a more meaningful contribution in improving understanding and ability to develop planning and control systems, especially in the field of budgeting and Human Resources

2) For the company

Companies are advised to continue to increase the participation of the management of the company in preparing the budget so that the budget can reflect the voice of management as a whole. On budgeting process, lower management has the authority to participate as well as in budget submissions, trends budget produced by managers it will be more objective because information in each section can be included in the company's budget. Besides that, budget participation allows managers to channel knowledge, abilities and expertise for creativity to improve managerial performance.

\section{References}

Anggraeni, Merina. 2010. Pengaruh Komitmen Organisasi, Pengendalian Intern, dan PrinsipPrinsip Good Corporate Governance Terhadap Kinerja pada PT. PLN (Persero) Distribusi Jawa Timur APJ Jember. Skripsi Fakultas Ekonomi Universitas Jember.

Arisandi, Theo, 2007. Pengaruh Partisipasi Anggaran terhadap Kinerja Manajerial pada PT. Suritani Pemuka di Kabupaten Banyuwangi. Skripsi Fakultas Ekonomi Universitas Jember.

Cut Zurnali. 2010. Knowledge Worker: Kerangka Riset Manajemen Sumber Daya Manusia Masa Depan. Bandung : Penerbit Unpad Press

Prasetyo Nugroho. 2018. Pengaruh Partisipasi Anggaran Dan Komitmen Organisasi Terhadap Kinerja Manajerial (Studi Empiris Pada Pemda Kabupaten Pekalongan, Pemda Kota Pekalongan, dan Pemda Kabupaten Sleman). Skripsi Fakultas Ekonomi Akuntansi Universitas Islam Indonesia, Yogyakarta

Putri Elinda Yuniar. 2015. Pengaruh Partisipasi Anggaran, Komitmen Organisasi, Dan Ketidakpastian Lingkungan Terhadap Kinerja Manajerial. Jurnal Akuntansi Universitas Muhammadiyah Surakarta 
International Journal of Economics, Business and Accounting Research (IJEBAR)

Peer Reviewed - International Journal

Vol-4, Issue-2, 2020 (IJEBAR)

E-ISSN: 2614-1280 P-ISSN 2622-4771

http://jurnal.stie-aas.ac.id/index.php/IJEBAR

Sugiyono. 2016. Metode Penelitian Kuantitatif, Kualitatif, R\&D. Bandung : IKAPI

Triyokananta, Vemti. 2006. Pengaruh Partisipasi Anggaran dan Motivasi Terhadap Prestasi Kerja. Skripsi Fakultas Ekonomi Universitas Jember.

Wahyuningsih, Sri Indah. 2005. Pengaruh Partisipasi Anggaran Terhadap Kinerja Manajerial dengan Persepsi Peran sebagai Variabel Moderating (Studi Empiris pada PT. Kereta Api (Persero) DAOP IX Jember). Skripsi Fakultas Ekonomi Universitas Jember. 